\title{
PEMETAAN JENIS PEKERJAAN PRODUKSI PADA INDUSTRI BUSANA MITRA PRAKTIK INDUSTRI MAHASISWA PROGRAM STUDI TATA BUSANA
}

\author{
Endang Prahastuti ${ }^{1}$, Rizky Yulianingrum Pradani ${ }^{2}$ \\ ${ }^{1}$ Program Studi Tata Busana Universitas Negeri Malang; ${ }^{2}$ Program Studi Tata Busana Universitas Negeri Malang \\ E-mail: endang.prahastuti.ft@um.ac.id
}

\begin{abstract}
ABSTRAK
Penelitian ini bertujuan untuk memetakan jenis pekerjaan produksi yang tersedia pada industri busana mitra Praktik Industri (PI) mahasiswa program studi tata busana. Rancangan penelitian yang digunakan adalah penelitian deskriptif kuantitatif. Populasi penelitian ini pemilik industri busana yang memiliki perjanjian kerjasama dengan pihak program studi sebagai tempat magang mahasiswa pada tahun 2017 sejumlah 21 industri busana tempat PI. Instrumen penelitian yang digunakan adalah angket tertutup dan wawancara tidak terstruktur. Instrumen diuji menggunakan teknik validitas konstruk.Teknik analisis data yang digunakan adalah analisis statistik deskriptif dengan persentase. Hasil penelitian menunjukkan bahwa: (1) 25\% Industri Butik mengelola 17-24 jenis pekerjaan produksi, 75\% mengelola 9-16 jenis pekerjaan produksi, (2) 66,6\% Industri Modiste mengelola 17-24 jenis pekerjaan produksi, 22,2\% mengelola 9-16 jenis pekerjaan produksi, $11,1 \%$ mengelola 18 jenis pekerjaan produksi, dan (3) 50\% Industri Garmen mengelola 9-16 jenis pekerjaan produksi, dan 50\% mengelola 1-8 jenis pekerjaan produksi. Industri mitra mengelola jenis pekerjaan yang bervariasi sesuai dengan besar kecilnya quota pesanan, variasi kelengkapan jenis pekerjaan pada industri diperlukan untuk penyelaras ketidakseragaman kompentensi yang dikuasai mahasiswa.
\end{abstract}

Kata Kunci: industri busana, praktik industri

\section{PENDAHULUAN}

Praktek Industri (PI) merupakan kegiatan magang yang diselenggarakan di perguruan tinggi bersama industri mitra. Dimana kegiatan ini membangun kerjasama antara lembaga pendidikan yang bersangkutan dengan dunia usaha atau dunia industri. Kegiatan PI dikenal dengan berbagai sebutan. Di SMK biasanya dikenal dengan sebutan Praktek Kerja Industri (Prakerin). Di universitas PI juga dikenal dengan sebutan Praktek Kerja Lapangan(PKL). Namun pada hakikatnya PKL, PI atau Prakerin tersebut sama, bertujuan untuk memberikan kesempatan pada mahasiswa atau siswa untuk melengkapi kompetensi secara langsung di dunia kerja.

Pada penelitian tentang pelaksanaan Praktek Industri di Program Studi Tata Busana Universitas Negeri Malang diperoleh kesimpulan bahwa program PI sudah berjalan sesuai dengan pedoman PI [11]. Sejenis dengan penelitian tersebut yakni tentang peluang yang diberikan industri butik kepada mahasiswamagang tersedia hampir di semua lini produksi [7]. Di sisi lain, pada penelitian tantang Garmen, ditemukan bahwa pekerjaan pada industri mitra yang bersifat sangat penting (membuat pola) tidak diberikan kesempatan kepada mahasiswa maupun pekerja dalam industri tersebut untuk memperoleh pengalaman [5]. Berdasarkan latar belakang tersebut maka menjadi penting untuk mengkaji tentang "Pemetaan Jenis Pekerjaan Pada Industri Busana Mitra Praktik Industri Mahasiswa Tata Busana”.

\section{PRAKTIK INDUSTRI}

Praktik industri adalah suatu komponen praktik keahlian profesi, berupa kegiatan secara terprogram dalam situasi sebenarnya untuk 
mencapai tingkat keahlian dan sikap kerja profesional yang dilakukan di industri (Sambas, 2010). Praktik industri atau praktik kerja lapangan adalah bekerja di luar kelas pada suatu establishment atau instansi yang sedang beroperasi. Bekerja disini dimaksudkan sebagai upaya penerapan dan pembandingan antara pekerjaan yang nyata dengan teori-teori yang didapat siswa atau mahasiswa di dalam kelas sebagai bagian dari kurikulum yang diwajibkan untuknya”(Bartono dalam Ritudina, 2013)

Pedoman Praktik Industri Jurusan Teknologi Industri [3] menyatakan bahwa " Praktik Industri merupakan salah satu matakuliah intrakulikuler yang termasuk dalam mata kuliah praktik pengalaman lapangan (PPL) Non Kependidikan dengan bobot 3 sks/12 js. PI dilaksanakan secara terprogram, terpadu dan terbimbing melalui kegiatan pelatihan (magang) pada industri/perusahaan mitra”. Keberhasilan pelaksanaan PI sangat tergantung dari kerjasama yang baik dan keterlibatan secara aktif antara pihak sekolah dan dunia industri yang menjadi institusi pasangan. Proses pembelajaran dalam PI harus mampu memadukan secara sistematis kedua tempat tersebut sehingga menjadi suatu tempat belajar yang saling menunjang, sehingga setelah selesai melaksanakan kegiatan praktik industri peserta didik diharapkan betul-betul menguasai suatu keterampilan kerja serta memiliki tambahan wawasan terhadap dunia kerja.

Melalui PI diharapkan mahasiswa memiliki kesempatan untuk menerapkan pengetahuan dan keterampilan bidang busana pada industri/ perusahaan, memperoleh pengalaman bekerja secara nyata, serta mampu menganalisis manajemen usaha yang diterapkan pada persahaan/ industri tempat praktik. Menurut Sitompul (2012) menyebutkan tujuan penyelenggaraan praktik industri adalah:

a. Dapat menambah dan mengembangkan potensi ilmu pengetahuan pada masingmasing siswa/i.

b. Melahirkan sikap bertanggung jawab, disiplin, sikap mental, etika yang baik serta bersosialisasi dengan lingkungan sekitar. c. Menambah kreatifitas siswa/i agar dapat mengembangkan bakat yang terdapat dalam dirinya.

d. Melatih keterampilan yang dimiliki siswa/i sehingga dapat bekerja dengan baik.

e. Memberikan motivasi sehingga siswa/i bersemangat dalam meraih cita-cita mereka.

f. Melatih siswa/i agar dapat membuat suatu laporan yang terperinci dari apa saja yang mereka kerjakan selama Praktik Kerja Industri.

Menurut Bartono dalam Rituadina (2013) dengan praktik industri mahasiswa diharapkan akan dapat membandingkan teori dan praktik, antara idealisme dan realitas,disamping itu praktik industri juga mampu menambah pengetahuan yang belum diberikan di dalam kelas sehingga pengetahuannya semakin lengkap lewat praktik kerja di lapangan. Melalui praktik industri mahasiswa dapat mengamati secara langsung keadaan di industri dan melakukan studi perbandingan antara ilmu yang didapat pada saat kuliah dengan ilmu yang diterapkan di lapangan.

\section{MODISTE, BUTIK, DAN GARMEN}

Modiste, butik, dan garmen memiliki persamaan dan perbedaan yakni pada produk dan proses produksi busananya. Modiste memproduksi busana secara custom sesuai dengan ukuran pemesan. Butik disamping memproduksi busana secara custom biasanya juga menjual busana dalam ukuran standar tertentu dengan jumlah produksi yang terbatas. Sedangkan Garmen membuat satu model dengan beberapa standar ukuran dan dalam jumlah banyak (ribuan) per ukurannya, seperti jas almamater, seragam olah raga, dan produk mass production yang lain.

Dari ketiga jenis industri busana tersebut, modiste merupakan usaha busana yang bersifat industri rumahan karena biasanya cukup dikerjaan oleh 1-2 karyawan dan1pengelola merangkap karyawan sudah dapat menyelesaikan semua pesanan. Seorang karyawan modiste umumnya dapat 
mengerjakan semua jenis pekerjaan produksi mulai dari membuat pola, memotong, menjahit, dan menyelesaikan jahitan (finishing). Dalam usaha modiste pelanggan mempunyai sensitifitas ukuran yang sangat tinggi, produk harus benar benar dikerjakan sesuai dengan kemauan pemesan. Pengalaman pada beberapa modiste banyak pelanggan yang secara dominan menekan modiste untuk mengikuti kemauan pemesan walaupun terkadang secara produksi inefisiensi dan atau hasilnya tidak sesuai standar produksi. Usaha modiste lebih banyak menekankan pada kepuasan konsumen dari segi kenyamanan produk dan waktu pengerjaan sehingga kadang terjadi tumpang tindih waktu pengerjaan antara pesanan yang awal dengan pesanan yang selanjutnya.

Selanjutnya, Butik berasal dari bahasa Perancis yaitu boutique. Butik menurut KBBI adalah toko pakaian eksklusif yang menjual pakaian modern yang sesuai dengan mode terkini, dengan segala kelengkapannya (terutama untuk wanita). Ada juga yang mendeskripsikan sebagai "suatu usaha pembuatan busana dengan jahitan kualitas tinggi dengan penjualan pelengkap busananya" (Riyanto, 2003).

Kondisi saat ini Butik adalah tempat menjual produk clothing yang sedang menjadi trend pada masyarakat luas, baik untuk busana yang diproduksi serial maupun busana dengan mode yang unik. Busana busana tersebut biasanya sudah dilengkapi dengan padanan aksesoris yang juga sedang in. Produk Butik tidak hanya sekedar barang berkualitas tinggi yang digemari masyarakat namun juga selaras dengan harganya yang sangat tinggi, sehingga disebut sebagai manufaktur butik (Yerusalem, 2012). Dengan demikian industri Butik mestinya terdiri dari rangkaian jenis pekerjaan spesifik yang saling terkait dalam pengelolaan manajemen yang professional mulai dari riset untuk menciptakan trend, sampling, pattern, cutting, sewing, sampai dengan finishing dan packaging.

Pada suatu industri Garmen, produk busana diproduksi menggunakan ukuran standart industri tertentu, atau sesuai dengan standar ukuran yang diminta oleh masing masing buyer. Bahkan ukuran tersebut seringkali termasuk ukuran polanya, sebagaimana yang tertera pada sistem standar ukuran.Sebagai contoh,untuk Standar industri Nasional Indonesia (SNI, kemeja pria dewasa kain tenun dimulai dari nomor15 s/d nomor 19, dalam daftar tersebut juga disajikan ukuran dalam bentuk pola sehingga tanpa belajar membuat polapun bisa membaca dan menyalin pola tersebut. Pada industri Garmen dikenal dengan istilah penggunakan sistem "ban berjalan”. Artinya, sebuah pakaian tidak dijahit tuntas oleh seorang penjahit. Masing masing bagian seperti: jahit kerah, jahit saku, pressing, dan bagian bagian yang lain dikerjakan oleh masing-masing pekerja yang ahli dalam bidang tersebut. Pekerjaan tersebut dikerjakan oleh beberapa orang pekerja berurutan sesuai dengan efisiensi kerja atau tertib kerjanya [6].

Label sebagai identitas produk garmen yang dipergunakan oleh industri dapat berasal dari buyer yang memesan atau label tertentu yang biasa digunakan oleh industri tersebut. Biasanya sebuah garment mempunyai lebih satu macam label yang terdiri dari label utama (main label), label grade 2 (second label), dan label label titipan dari berbagai buyer.

Pada garment manufacturing secara garis besar urutan jenis pekerjaan pada industri garmen adalah: designing, patternmaking, fit sample making, production pattern making, grading, marker making, fabric spreading, fabric cutting, bundling, sewing, garment inspection, garment ironing and finishing, final inspection, garment packing, and cartooning.

\section{METODE}

Penelitian ini merupakan penelitian deskriptif dengan pendekatan kuantitatif. Populasi dalam penelitian ini adalah seluruh pengelola usaha busana yang menjadi mitra program studi sebagai tempat Praktek Industri mahasiswa D3 dan S1 Pendidikan Tata Busana tahun 2017. Jumlah keseluruhan populasi 
adalah 21 industri busana yang berlokasi di daerah Malang, Tulungagung, dan Surabaya (Jawa Timur). Keseluruhan anggota populasi diambil semua sebagai sampel dari penelitian ini dengan tujuan untuk memperoleh data jenis pekerjaan produksi pada industri mitra tahun 2017 secara lengkap.

Instrumen dirancang dalam bentuk angket tertutup menggunakan skala Guttman dengan pilihan jawaban "Ada” bila tersedia jenis pekerjaan pada industri tersebut, dan “Tidak" bila jenis pekerjaan yang ditanyakan tidak ada. Jenis angkat terbagi menjadi 3 sesuai dengan katagori industri yakni kelompok modiste, butik, dan garmen. Validasi instrument menggunakan validasi konstruk yang divalidasi oleh para pakar pada bidang modiste, butik, dan garmen.

Data yang terkumpul dianalisa secara prosentasenya, dan dikatagorikan sesuai klasternya

\section{HASIL DAN PEMBAHASAN HASIL}

Komposisi dari 21 industri mitra yang berada di jawa timur adalah sebagai berikut: 9 adalah Modiste, 8 Butik, dan 4 Garmen.

Hasil analisis data diperolah sebagai berikut. (1) Pada Modiste: 66,6\% modiste sangat baik yang mengelola $17-24$ jenis pekerjaan produksi, 22,2\% modiste baik yang mengelola 9-16 jenis pekerjaan produksi, dan sisanya sebesar $11,1 \%$ modiste kurang baik yang hanya mengelola 1-8 jenis pekerjaan produksi, (2) Pada Butik: 25\% Butik sangat baik yang mengelola 17-24 jenis pekerjaan produksi, 75\% Butik baik yang mengelola 9-16 jenis pekerjaan produksi, (3) Pada Garmen: 50\% Garmen baik yang mengelola 9-16 jenis pekerjaan produksi, dan 50\% Garmen kurang baik yang hanya mengelola 1-8 jenis pekerjaan produksi.

\section{PEMBAHASAN}

Jenis pekerjaan yang dikelola Modiste mitra terbagi menjadi tiga klaster:

(1) Jenis Pekerjaan pada Modiste katagori sangat baik,
(2) Jenis Pekerjaan pada Modiste katagori baik

(3) Jenis Pekerjaan pada Modiste katagori kurang baik

Menurut SKKNI No. 91/2008 tentang Sektor Jasa Penjaitan bahkan ada 4 katagori jasa penjaitan yakni: asisten pembuat pakaian, pembuat pakaian, penyelia proses pembuat pakaian, dan pengelola pembuat pakaian. Sesuai dengan standar tersebut jenis pekerjaan pada industri modiste mitra masih memenuhi syarat sebagai tempat magang mahasiswa tata busana.

Butik mitra sebagai tempat magang mahasiswa terbagi menjadi 2 katagori yakni:

Jenis Pekerjaan pada Butik katagori sangat baik dan Jenis Pekerjaan pada Butik katagori baik

Butik katagori baik sudah mengelola lebih dari separo jenis pekerjaan yang dikelola oleh butik dengan katagori sangat baik. Jenis pekerjaan yang dikurangi pada butik katagori baik secara umum merupakan jenis pekerjaan yang diperlukan bila butik tersebut berorientasi ekspor sehingga dipandang masih cukup relevan apabila sebagian besarbutik mitra digunakan sebagai tempat magang mahasiswa tata busana.

Garmen mitra terbagi menjadi dua katagori dengan komposisi yang sama yakni:

(1) Jenis Pekerjaan pada Garmen katagori baik

(2) Jenis Pekerjaan pada Garmen katagori kurang baik

Jenis pekerjaan pada Garmen sangat tergantung pada besarnya kuota pesanan dan alat yang disediakan untuk mengerjakan pesanan tersebut. Tujuan utama dari industri Garmen adalah memproduksi berbagai jenis pakaian jadi yang berkualitas dari tekstil sesuai kebutuhan pasar (SKKNI 305/2015). Dengan demikian garmen dengan hanya mengelola 1-8 jenis pekerjaan biasanya merupakan industri sub yang mensuplai produk pada industri garmen yang lebih lengkap

Dari ketiga macam industri busana mitra mahasiswa, secara umum dapat disimpulkan bahwa variasi jenis pekerjaan yang tersedia di industri mitra masih relevan dengan tujuan 
menempatkan mahaiswa PI pada industri. Disamping itu, variasi jenis pekerjaan justru diperlukan mengingat kompetensi mahasiswa tidak selalu persis sama sehingga perlu disediakan penyelaras pada dunia industri.

\section{SIMPULAN}

1. Peta jenis pekerjaan pada industri busana mitra terdiri dari 3 katagori

2. Industri mitra mengelola jenis pekerjaan yang bervariasi sesuai dengan besar kecilnya quota pesanan pada masing masing industri

3. Variasi kelengkapan jenis pekerjaan pada industri diperlukan untuk penyelaras ketidakseragaman kompentensi bidang studi yang dikuasahi mahasiswa.

\section{REFERENSI}

[1] Islam. M. 2015. Flow Chart of Garments Manufacturing Process / Technology. Dhaka

[2] Jerusalem, M.A. 2012. Merintis dan Mengelola Bisnis Butik. Yogyakarta: Universitas Negeri Yogyakarta.

[3] Jurusan Teknologi Industri FT UM. 2010. Pedoman Praktik Industri. Malang: Universitas Negeri Malang.

[4] Katalog Fakultas Teknik Jurusan Teknologi Industri. 2010. Malang: Universitas Negeri Malang.

[5] Mustikasari, D. 2017. Skripsi: Studi Tentang Kopetensi Pekerja Industri Busana Di CV AmartaWisesa Malang
Berdasarkan Standar Kompetensi Kerja Nasional Indonesia Sektor Garmen. Malang: UM

[6] Prahastuti, E. 2016. Prinsip Produksi Busana Industri. Malang: UM

[7] Sari, N.M.2015. Skripsi: Pemetaan peluang pembelajaran pada butik tempat praktik industri mahasiswa s1 dan d3 tata busana tahun 2015 . Malang: UM

[8] SKKNI No. 91/2008 tentang Sektor Jasa Penjaitan

[9] SKKNI No.305/2015 tentang Industri Pengolahan Bidang Produksi Pakaian jadi

[10] Wiyono, B.B. 2007. Metodologi Penelitian (Pendekatan Kuantitatif, Kualitatif, dan Action Research) (Burhanudin, Ed.).Malang: Fakultas Ilmu Pendidikan Universitas Negeri Malang

[11] Wulandari, Y. 2014. Skripsi: Studi tentang kesesuaian pelaksanaan praktik industri dengan buku pedoman praktik industri mahasiswa s1 pendidikan tata busana jurusan teknologi industri universitas negeri malang angkatan 2010. Malang: $\mathrm{UM}$ 